\title{
Spatial distribution of Chagas disease and its correlation with health services*
}

\section{Distribuição espacial da doença de Chagas e sua correlação com os serviços de saúde Distribución espacial de la enfermedad de Chagas y su correlación con los servicios sanitarios}

How to cite this article:

Cardoso LP, Paiva TR, Nogueira LMV, Guimarães RJPS, Rodrigues ILA, André SR. Spatial distribution of Chagas disease and its correlation with health services. Rev Esc Enferm USP. 2020;54:e03565. doi: https://doi.org/10.1590/S1980-220X2018058603565

\section{Luana Pastana Cardoso ${ }^{1}$ \\ Thayse Reis Paiva ${ }^{1}$ \\ Laura Maria Vidal Nogueira ${ }^{1}$ \\ Ricardo José de Paula Souza e Guimarães $^{2}$ \\ D Ivaneide Leal Ataíde Rodrigues ${ }^{1}$ \\ Suzana Rosa André ${ }^{1}$}

* Extracted from the Undergraduate Thesis: "Padrão Espacial da Doença de Chagas e sua Correlação com os Serviços de Saúde em um município ribeirinho na Amazônia Brasileira", Departamento de Enfermagem, Universidade Estadual do Pará, 2018.

${ }^{1}$ Universidade do Estado do Pará,

Escola de Enfermagem Magalhães

Barata, Belém, PA, Brazil.

${ }^{2}$ Instituto Evandro Chagas, Laboratório de Geoprocessamento, Ananindeua, PA, Brazil.

\section{ABSTRACT}

Objective: To analyze the spatial distribution of Acute Chagas Disease (ACD) cases in a riverside municipality and make relationships with the notifying health services. Method: Longitudinal, ecological, quantitative study with use of geoprocessing techniques, conducted with cases of acute Chagas disease in the municipality of Abaetetuba/Pará. Results: Inclusion of 204 disease cases. Predominance of the male sex, mixed race and primary education as educational level. The highest incidence of cases was found in rural areas and the infection via oral transmission predominated. ACD is not randomly distributed in the geographic space and the diagnosis is centralized in the Epidemiological Surveillance service of the municipality. Conclusion: Acute Chagas disease is closely related to the sociodemographic conditions of the population. The spatial analysis of cases allowed to observe the disease spatial pattern and the need for Primary Care network organization for timely care near the residence of people affected.

\section{DESCRIPTORS}

Chagas Disease; Epidemiology; Health Services; Geographic Information Systems; Spatial Analysis; Public Health Nursing. 


\section{INTRODUCTION}

The object of this study was the Acute Chagas Disease (ACD) and the Health Care Network. Chagas disease is considered an anthropozoonosis, a disease that connects man to animals from the domiciliation of vectors displaced from their habitat by men's action in the environment ${ }^{(1)}$. According to the World Health Organization, this disease is caused by the protozoan Trypanosoma cruzi and has affected 6 to 7 million people worldwide, mainly in Latin America, where in most cases, the parasite is transmitted to humans through contact with triatomine feces and urine ${ }^{(2)}$.

In Brazil, 1,510 cases of ACD were reported between 2010 and 2016, out of which 1,426 (94.4\%) originating from the northern region, and of these, 1,220 (80.8\%) were from the state of Pará. Of this total number in the state, the expressive number (191) of cases reported in the municipality of Abaetetuba (12.6\%) draws attention, while the remainder are dispersed in other municipalities of Pará. Another relevant aspect in this epidemiological context, concerns the predominance of oral transmission in notifications of the state of Pará, corresponding to 1,025 cases $(84 \%)$ of the total ${ }^{(3)}$.

Most cases of ACD in the Amazon region are related to oral transmission through ingestion of sugarcane juice or acai juice ${ }^{(4)}$. Acai consumption is very present in the diet of the population of Pará, especially in riverside populations and residents of more distant areas of the metropolitan region of Belém ${ }^{(5)}$.

ACD is strongly intertwined with poverty and social inequality, so the situation of vulnerability, urbanization, lack of access to health services and specific actions involving the disease components - humans, vectors of the genera Triatoma, Rhodnius and Panstrongylus and Trypanosoma cruzi - intensify the disease picture in the state of Pará ${ }^{(6)}$ with a concentration of cases in the municipality of Abaetetuba, where a higher incidence of the acute form has been recorded $^{(3,7)}$.

The identification and diagnosis of ACD cases should occur in the primary care network, which needs trained professionals, laboratory support, therapeutic diagnosis and specialized backup in necessary situations ${ }^{(8)}$.

In this sense, the aim of the present study was to analyze the spatial distribution of ACD cases in the municipality of Abaetetuba and its relationship with the notifying health services.

\section{METHOD}

\section{TYPE OF STUDY}

This is a longitudinal, ecological, quantitative study.

\section{Population}

The study included all new cases of ACD notified and confirmed in the Notifiable Diseases Information System (Portuguese acronym: SINAN) between 2010 and 2016, obtained from the Municipal Health Secretariat of Abaetetuba, corresponding to 204 cases. The choice for the period is justified by the need to evaluate the behavior of the $\mathrm{ACD}$ and the dynamics of health services before and after the registration of a possible outbreak in $2012^{(9)}$.

The notification forms selected for the study should have the following fields completed: year of notification; confirmed case of acute Chagas disease; patient's full address; address of the notifying health center.

\section{Data collection}

In March 2018, the database of ACD cases in the Health Notification Information System was obtained from the Abaetetuba Municipal Health Department. These data were recorded and tabulated in a Microsoft Excel spreadsheet for debugging and construction of the georeferenced database. Data debugging was performed for selecting only the files containing the previously established inclusion criteria.

\section{DATA ANALYSIS AND PROCESSING}

After data debugging, the georeferenced database was constructed through the coordinates of the health centers and the patients' home locations. The Garmin GPSMap 64s Global Positioning System (GPS) and the cartographic base of the Brazilian Institute of Geography and Statistics (Portuguese acronym: IBGE) were used ${ }^{(10)}$. The georeferenced database was exported to a Geographic Information System (GIS) for visual expression and spatial analysis of data on digital maps.

The Kernel Density Estimator (KDE) was applied using the parameters of quartic function and adaptive radius in TerraView 4.2.2 software in order to obtain the behavior of point patterns and provide the intensity of the point process throughout the studied area.

Statistical analyzes were performed using the Statistical Package for the Social Sciences (SPSS), version 24.0. The Pearson's chi-square nonparametric test was used and were adopted a significance level of $5 \%$ and $p$-value $<0.05$.

\section{ETHICAL ASPECTS}

The study was approved by the Research Ethics Committee under number 2.344.626 in 2017.

\section{RESULTS}

According to Table 1, there was a higher number of cases in $2012(\mathrm{n}=62 ; 30.39 \%)$ with an incidence rate of $42.93 / 100$ thousand inhabitants. The year 2011 had the lowest incidence rate of the disease, 7/100 thousand inhabitants.

Still in Table 1, most cases of ACD were reported in the municipality itself ( $\mathrm{n}=182 ; 89.21 \%)$, and only $10.78 \%$ $(n=22)$ had the diagnosis made in the state capital, Belém and in the municipality of Ananindeua that is part of the metropolitan area. The concentration of ACD diagnoses in the Epidemiological Surveillance Service ( $\mathrm{n}=151 ; 74.02 \%$; $\mathrm{p}<0.0001$ ) of the municipality of Abaetetuba is noteworthy. This service is linked to the Municipal Health Secretariat that meets the spontaneous demand of suspected cases of infectious diseases. 
Table 1 - Description of cases of Acute Chagas Disease reported in the municipality of Abaetetuba from 2010 to 2016 - Belém, PA, Brazil, 2018.

\begin{tabular}{|c|c|c|c|}
\hline Notification year & n & $\begin{array}{c}\text { Percentage } \\
\qquad \%)\end{array}$ & $\begin{array}{c}\text { Incidence } \\
\text { rate }(\%) \\
(100 \text { thousand } \\
\text { inhab.) }\end{array}$ \\
\hline 2010 & 23 & 11.27 & 16.30 \\
\hline 2011 & 10 & 4.9 & 7.00 \\
\hline 2012 & 62 & 30.39 & 42.93 \\
\hline 2013 & 18 & 8.82 & 12.22 \\
\hline 2014 & 34 & 16.67 & 22.84 \\
\hline 2015 & 22 & 10.78 & 14.62 \\
\hline 2016 & 35 & 17.16 & 23.04 \\
\hline Notifying unit & & & P-value ${ }^{(1)}$ \\
\hline Belém & $\underline{13}$ & $\underline{6.37}$ & \multirow{10}{*}{$<0.0001^{* * *}$} \\
\hline$\underline{\text { Ananindeua }}$ & $\underline{9}$ & $\underline{4.41}$ & \\
\hline$\underline{\text { Abaetetuba }}$ & $\underline{182}$ & $\underline{89.21}$ & \\
\hline Santa Rosa Municipal Hospital & 5 & 2.45 & \\
\hline Julia Seffer Hospital & 6 & 2.94 & \\
\hline Abaetetuba General Hospital & 16 & 7.84 & \\
\hline Abaetetuba Health Center & 2 & 0.98 & \\
\hline Epidemiological Surveillance Service & 151 & 74.02 & \\
\hline Algodoal Family Health Unit & 1 & 0.49 & \\
\hline Aviação Family Health Unit & 1 & 0.49 & \\
\hline Total & 204 & & \\
\hline
\end{tabular}

Sources: National Register of Health Facilities (CNES). Health Notification Information System (SINAN), 2018. (1) Pearson's chi-square test for independence ( $\mathrm{p}$-value $<0.05)$.***Highly significant values. $\mathrm{H}_{1}$ : The incidence rate depends on categorical variables $(\mathrm{p}<0.05)$.
Figure 1 shows the spatial dimension of rural and urban areas, the spatial location of ACD cases and the Health Centers in the municipality. There is a dispersion of cases in the territory, but there is a concentration of diagnosis, especially in the Epidemiological Surveillance Service located in the urban perimeter of the municipality.

Table 2 shows that the frequency and incidence rate of cases were higher among men, with 154.96/100 thousand inhabitants, while in women the rate was of $133.87 / 100$ thousand inhabitants. However, this difference was not statistically significant $(\mathrm{p}=0.3312)$.

The high percentage $(82.76 \%)$ of cases in the mixed-race population stood out compared to the others. The predominant level of education was primary school, corresponding to $55.39 \%$ (133) of total cases.

Acute Chagas disease cases were reported in both urban and rural residents of the municipality. However, proportionally, the incidence rate in rural areas was higher than in urban areas (168.67/100 inhabitants; $\mathrm{p}<0.0001)$.

According to Table 3, most cases of ACD were confirmed by laboratory exams ( 195 cases; $95.59 \%)$. Of the total studied, only two cases $(0.98 \%)$ resulted in death, and the main source of infection was oral $(177 ; 86.76 \%)$.

Figure 2 shows the result of applying the KDE. The regions indicated show the higher case density in rural areas in 2010, 2011 and 2015 and in urban areas in 2012, 2013, 2014 and 2016. The analysis of all cases allowed the visualization of a non-random distribution in the geographic space.

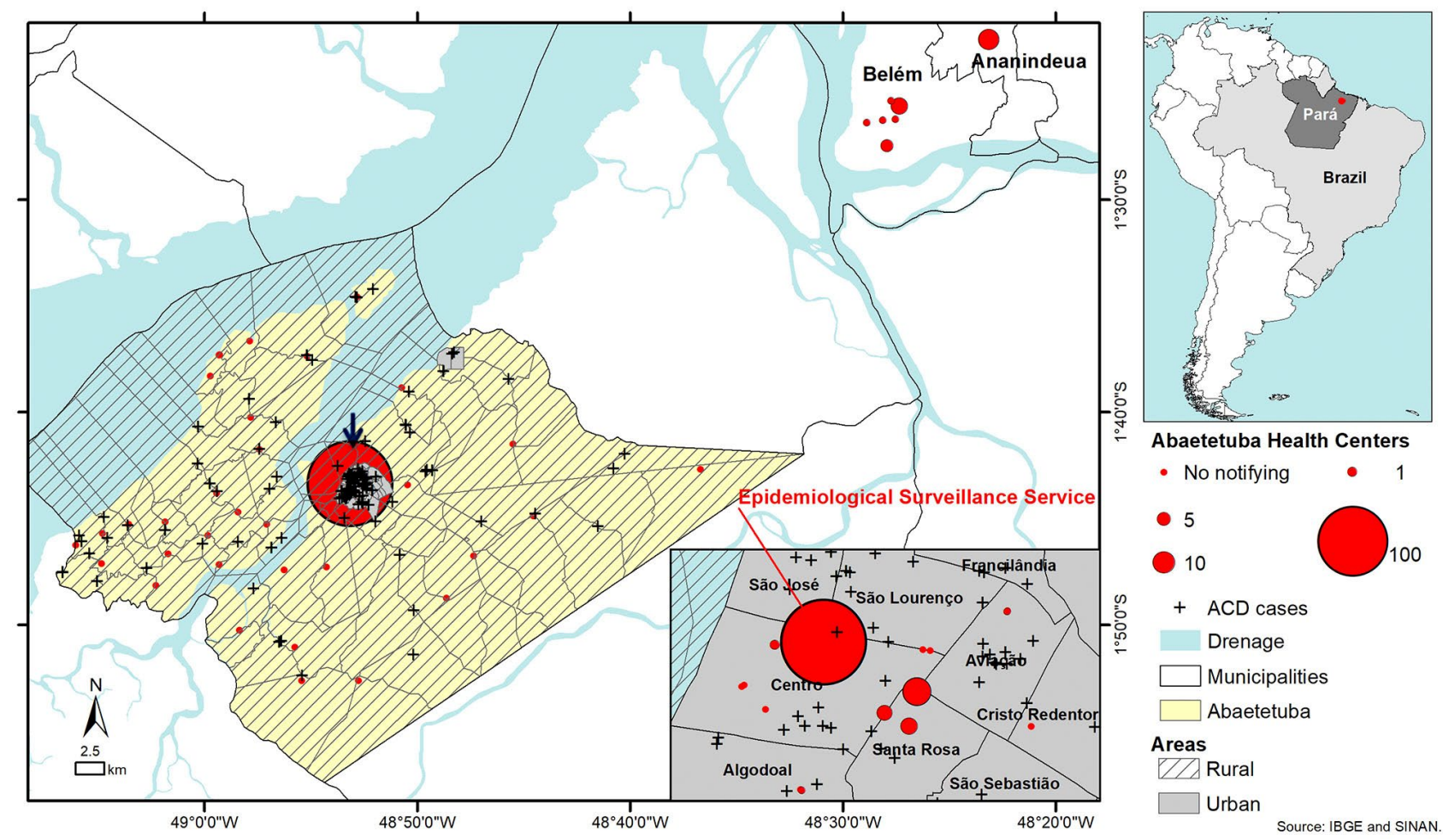

Figure 1 - Spatial dimension of rural and urban areas, spatial location of ACD cases and Abaetetuba Health Centers. 
Table 2 - Description of the sociodemographic profile of acute Chagas disease cases reported in the municipality of Abaetetuba from 2010 to 2016 - Belém, PA, Brazil, 2018.

\begin{tabular}{|c|c|c|c|c|}
\hline Variable & $\mathrm{N}$ & Percentage (\%) & $\begin{array}{c}\text { Incidence rate (\%) } \\
\text { (x } 100 \text { thousand inhab.) }\end{array}$ & P-value \\
\hline \multicolumn{5}{|l|}{ Sex } \\
\hline Female & 93 & 45.59 & 133.87 & \multirow{2}{*}{0.3312} \\
\hline Male & 111 & 54.41 & 154.96 & \\
\hline \multicolumn{5}{|l|}{ Race } \\
\hline White & 27 & 13.3 & \multirow{4}{*}{ - } & \multirow{4}{*}{$<0.0001^{* * *}$} \\
\hline Black & 6 & 2.96 & & \\
\hline Mixed race & 168 & 82.76 & & \\
\hline Ignored & 2 & 0.99 & & \\
\hline \multicolumn{5}{|l|}{ Schooling } \\
\hline Illiterate & 8 & 3.92 & \multirow{8}{*}{-} & \multirow{8}{*}{$<0.0001^{* * *}$} \\
\hline Complete $1^{\text {st }}$ to $4^{\text {th }}$ grade & 65 & 31.86 & & \\
\hline Complete $5^{\text {th }}$ to $8^{\text {th }}$ grade & 48 & 23.53 & & \\
\hline Complete high school & 39 & 19.12 & & \\
\hline Incomplete higher education & 5 & 2.45 & & \\
\hline Complete higher education & 1 & 0.49 & & \\
\hline Ignored & 15 & 7.35 & & \\
\hline Not applicable & 23 & 11.27 & & \\
\hline \multicolumn{5}{|l|}{ Area } \\
\hline Urban & 99 & 49.49 & 119.28 & \multirow{3}{*}{$<0.0001^{* * *}$} \\
\hline Rural & 98 & 49.49 & 168.67 & \\
\hline Ignored & 7 & 0.51 & - & \\
\hline
\end{tabular}

Sources: National Register of Health Facilities (CNES). Health Notification Information System (SINAN), 2018. *** Highly significant values.

Table 3 - Description of clinical aspects of acute Chagas disease cases reported in the municipality of Abaetetuba from 2010 to 2016 - Belém, PA, Brazil, 2018.

\begin{tabular}{|c|c|c|c|}
\hline Confirmation criteria & $\mathbf{n}$ & Percentage (\%) & P-value \\
\hline Laboratory & 195 & 95.59 & \multirow{2}{*}{$<0.0001^{* * *}$} \\
\hline Clinical-epidemiological & 9 & 4.41 & \\
\hline \multicolumn{4}{|l|}{ Evolution } \\
\hline Alive & 198 & 97.06 & \multirow{3}{*}{$<0.0001^{* * *}$} \\
\hline Death & 2 & 0.98 & \\
\hline Ignored & 4 & 1.96 & \\
\hline \multicolumn{4}{|l|}{ Likely mode of infection } \\
\hline Vector & 17 & 8.33 & \multirow{4}{*}{$<0.0001^{* * *}$} \\
\hline Vertical & 1 & 0.49 & \\
\hline Oral & 177 & 86.76 & \\
\hline Ignored & 9 & 4.41 & \\
\hline
\end{tabular}

Sources: National Register of Health Facilities (CNES). Health Notification Information System (SINAN), 2018.

***Highly significant values. 

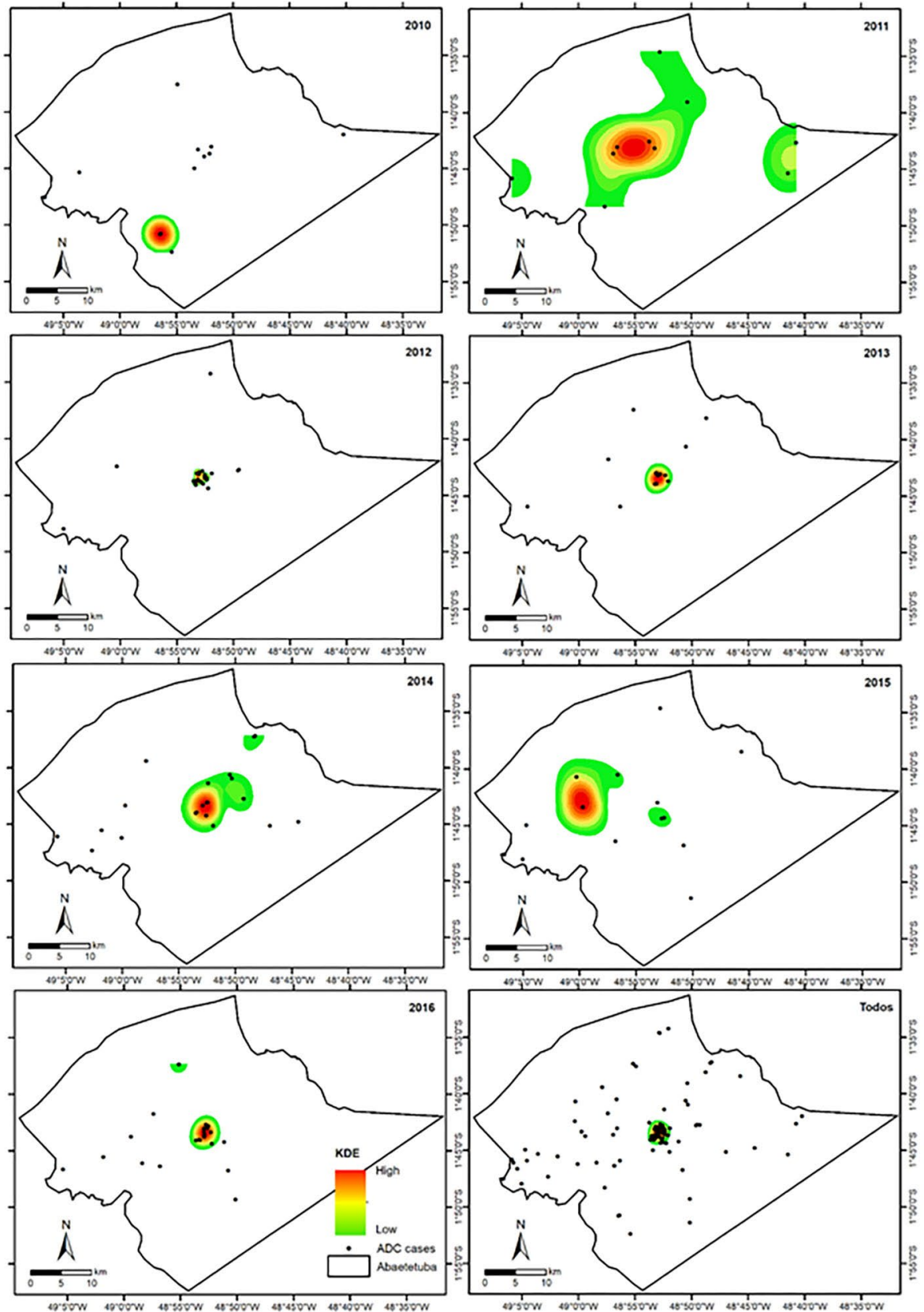

Figure 2 - Application of KDE in cases of ACD per year in Abaetetuba.

\section{DISCUSSION}

The spatial distribution of ACD in the municipality of Abaetetuba was non-random with oscillation in the occurrence of cases over the years studied. A higher record was identified in 2012 with outbreak characteristics, which is peculiar in the Amazon region because this is an endemic $\operatorname{area}^{(11)}$. These episodes are possibly potentiated by housing and environmental conditions associated with economic activities, such as the type of livestock in which there is deforestation that removes the vector from its natural environment and causes migration to other regions ${ }^{(12)}$.

ACD manifests itself differently in the geographic space, depending on the social profile. In the cases studied, a higher occurrence was identified among men, attributable to greater exposure due to mobility and circulation in places that favor
T. cruzi transmission ${ }^{(13)}$. There was a predominance in people who declared themselves as mixed race, similar to a study conducted in the municipality of Barcarena/Pará, in which the proportion of mixed-race subjects among patients with $\mathrm{ACD}$ was of $74.7 \%^{(14)}$. In another study conducted in Minas Gerais $^{(13)}$ a different result with a higher proportion of white subjects was obtained. This diversity of results may be related to the variety of ethnicities in Brazil ${ }^{(13)}$

Still related to the profile of cases, the disease was predominant among people with low education, corroborating the disease relationship with low quality social indicators and higher incidence in populations of greater social vulnerability ${ }^{(14)}$. In this group, there is greater exposure to triatomines, attributed (among other factors) to poor housing and 
environmental degradation, according to a study conducted in the municipality of Abaetetuba itself ${ }^{(12)}$.

Still exploring the municipality scenario, in another study, a change in the behavior of triatomines due to environmental changes was identified ${ }^{(15)}$, which leads vectors to invade the domestic environment ${ }^{(16)}$. In this sense, there is evidence of an association between the presence of triatomines and environmental characteristics altered by human occupation $^{(15,17)}$, especially deforestation that causes the migration of vectors to new areas, thereby generating oral transmission due to the proximity of handling food sites and the presence of contaminated triatomines ${ }^{(18)}$.

This form of transmission has been potentiated by the local culture of intense açai consumption, both the fresh and pulp forms, when contaminated by insect excrements ${ }^{(5)}$. Açai consumption in the state of Pará goes beyond its nutritional aspects and is also the result of a cultural process in which it stands out as the main dietary supplement for the local population ${ }^{(19)}$. The state's economy is also influenced by the commercialization of the product that represents an important source of income in the production and supply of juice for local and regional consumption, in addition to the distribution of açai pulp to other states and countries ${ }^{(19)}$.

The consumption of contaminated açai was responsible for the expressive number of cases classified as oral transmission in this study. Vector transmission can be attributed to the construction of houses in rural areas near açai/buriti palm trees that may be infested with triatomines and to the transformation of the forest area caused by deforestation, which lead to the invasion of vectors into households ${ }^{(12)}$. Both oral and vector transmission require coping measures from health authorities with preventive actions, early identification and treatment of cases, and follow-up of chronic cases. Furthermore, oral transmission seems to cause more severe clinical manifestations and higher mortality than vector transmission ${ }^{(20)}$.

It is important to highlight the $42.68 \%$ deforestation increase in Abaetetuba between 2000 and 2011 reached the entire population of the municipality ${ }^{(12)}$. The presence of this practice in the region has contributed to the migration of wild animals to peridomicile and domestic areas. Since such animals are food sources for the triatomine blood meal, there is a consequent movement of Triatoma to these environments ${ }^{(12,21)}$.

In relation to health services that reported $A C D$ cases, although the network of primary care units is well distributed spatially in the municipal territory, a concentration in the municipal epidemiological surveillance service was identified. This fact leads to the questioning of the quality of care offered to the population, from user embracement until resolution in clarifying the diagnosis. The migration of people seeking health care is a fact to be critically analyzed in the context of municipal management, as it may imply a delay in diagnosis and treatment, as well as excessive financial expenses for the family ${ }^{(22)}$.

According to the Ministry of Health, a reorganization of local epidemiological surveillance was necessary to provide more direction and agility in actions of disease prevention, diagnosis and control, as well as definition of care flows involving the health service network ${ }^{(23)}$. Therefore, the reality experienced with the occurrence of the outbreak in the municipality of Abaetetuba favored the care centralization in this service and led the population to search for it. This care strategy has had a result, since almost all cases have obtained diagnostic confirmation through laboratory exams.

Although primary care is the "gateway" to the health system, notification in these units was very low, and they should be prepared for case suspicion, early diagnosis and treatment, and reinforce prevention and control activities developed by local epidemiological surveillance ${ }^{(7,23)}$. Preventive actions are essential for preventing diseases and blocking their progress, and should cover all forms of transmission, including food control, especially in endemic areas ${ }^{(20)}$. Such actions are the attribution of all levels of care, which must be organized in the format of Health Care Networks (Portuguese acronym: RAS), defined as horizontal relations with integrated actions and services centralized in population demands, as well as quality, responsible, humanized care ${ }^{(8)}$.

For an effective and efficient response to patients with ACD, the Health Care Network must be organized with greater resolution in primary care, and trained multiprofessional teams for the development of disease control actions and provision of greater quality of life to infected patients ${ }^{(24)}$. The service provision close to patients' home can expedite decision-making power in ACD cases, and for people who live in banks of rivers and streams, whose travel is slow and costly due to the lack of public transportation, the search for healthcare at municipal headquarters is an aggravating factor of patients' conditions.

The limitations of this study relate to the use of secondary data, which may lead to case underreporting and record failures. Another aspect to be highlighted is the performance in a single municipality, even though it represents a significant notification in the state.

\section{CONCLUSION}

ACD in the municipality of Abaetetuba affects residents living in urban and rural areas, although in the epidemiological spectrum, the rural population is more affected. The disease is closely related to sociodemographic conditions, since it affected people with low education more expressively. The rural population inhabits a peculiar territory with rivers and forests, where, in addition to the culture of açai consumption, the juice preparation does not include all precautions regarding fruit hygiene, thereby contributing to the high rate of disease in the region.

Another aspect to be emphasized is the low responsiveness of the primary care network in the control of ACD, which became visible in the centralization of diagnosis in a service located in the urban perimeter of the municipality. This situation compromises control actions, since it requires displacement, often time consuming, because the municipality geography is formed by rivers and streams, and the only means of transportation is fluvial in small boats. Additionally, this transportation entails financial costs and becomes an added difficulty for many people. 
The difficulty of access to health services influences the outlook of the disease and potentiates its manifestation with outbreak characteristics. In addition, it results in even greater challenges to the local health management, namely: the early identification of potential geographical areas of ACD occurrence; combat of the focus of vectors; performance of health education practices in order to sensitize the population regarding oral transmission; and prompt response to the arising demands. There must be a systematic development of preventive actions and maintenance of an organized and resolute service network according to the population health needs.

Geoprocessing is an important tool to identify the disease location and pattern thereby enabling the adoption of appropriate measures for ACD control and follow-up of sequencing actions. This technique has great potential to help health managers to direct actions and services for the most exposed population groups, according to map information, besides contributing to the continuous and systematic disease surveillance.

\section{RESUMO}

Objetivo: Analisar a distribuição espacial dos casos de doença de Chagas aguda em um município ribeirinho e relacionar com os serviços de saúde notificantes. Método: Estudo ecológico, longitudinal, com abordagem quantitativa, que utilizou técnicas de geoprocessamento, realizado com casos de doença de Chagas aguda no município de Abaetetuba/Pará. Resultados: Foram estudados 204 casos. Predominou o sexo masculino, a "raça" parda e o ensino fundamental como nível de escolaridade. A maior incidência de casos foi constatada na zona rural e o modo de infecção predominante foi pela transmissão oral. A Doença de Chagas Aguda não se distribui de forma aleatória no espaço geográfico, e o diagnóstico é centralizado no serviço de Vigilância Epidemiológica do município. Conclusão: A doença de Chagas aguda está intimamente relacionada às condições sociodemográficas da população. A análise espacial dos casos permitiu visualizar o padrão espacial da doença e a necessidade da organização da rede de Atenção Primária à Saúde para atendimento oportuno às proximidades dos domicílios dos casos.

\section{DESCRITORES}

Doença de Chagas; Epidemiologia; Serviços de Saúde; Sistemas de Informação Geográfica; Análise Espacial; Enfermagem em Saúde Pública.

\section{RESUMEN}

Objetivo: Analizar la distribución espacial de los casos de enfermedad de Chagas aguda en un municipio ribereño y relacionar con los servicios sanitarios notificadores. Método: Estudio ecológico, longitudinal, con abordaje cuantitativo, que utilizó técnicas de geoprocesamiento, llevado a cabo con casos de enfermedad de Chagas aguda en el municipio de Abaetetuba/Pará. Resultados: Fueron estudiados 204 casos. Predominó el sexo masculino, la piel morena y la educación básica como nivel de escolaridad. La mayor incidencia de casos se constató en la zona rural y el modo de infección predominante fue por la transmisión oral. La Enfermedad de Chagas Aguda no se distribuye de modo aleatorio en el espacio geográfico, y el diagnóstico se centraliza en el servicio de Vigilancia Epidemiológica del municipio. Conclusión: La enfermedad de Chagas aguda está íntimamente relacionada con las condiciones sociodemográficas de la población. El análisis espacial de los casos permitió visualizar el estándar espacial de la enfermedad y la necesidad de la organización de la red de Atención Primaria de Salud para atención oportuna a las proximidades de los domicilios de los casos.

\section{DESCRIPTORES}

Enfermedad de Chagas; Epidemiología; Servicios de Salud; Sistemas de Información Geográfica; Análisis Espacial; Enfermería en Salud Pública.

\section{REFERENCES}

1. Morses SS, Mazet JAK, Woolhouse M, Parrish CR, Carroll D, Karesh WB, et al. Prediction and prevention of the next pandemic zoonosis. Lancet [Internet]. 2012 [cited 2018 May 10];380(9857):1956-65. Available from: https://www.ncbi.nlm.nih.gov/pmc/articles/PMC3712877/

2. World Health Organization. Chagas disease (American trypanosomiasis) [Internet]. Geneva: WHO; 2018 [cited 2018 May 10]. Available from: http://www.who.int/news-room/fact-sheets/detail/chagas-disease-(american-trypanosomiasis)

3. Brasil. Ministério da Saúde. Sistema de Informação de Agravos de Notificação (SINAN). Doença de Chagas Aguda: casos confirmados notificados no Brasil [Internet]. Brasília: SINAN; 2010-2016 [citado 2018 mar. 16]. Disponível em: http://tabnet.datasus.gov.br/cgi/tabcgi. exe?sinannet/cnv/chagasbr.def

4. Santos IFM. Transmissão oral da doença de Chagas: breve revisão. Rev Ciênc Méd Biol [Internet]. 2014 [citado 2018 mar. 18];13(2):22635. Disponível em: https://portalseer.ufba.br/index.php/cmbio/article/view/10034/9073

5. Xavier SCC, Roque ALR, Bilac D, Araújo VAL, Costa Neto SFC, Lorosa ES, et al. Distantiae transmission of Trypanosoma cruzi: a new epidemiological feature of acute Chagas disease in Brazil. PLoS Negl Trop Dis [Internet]. 2014 [cited 28 May 10];8(5):e2878. Available from: https://www.ncbi.nlm.nih.gov/pmc/articles/PMC4031066/

6. Ferreira RTB, Branquinho MR, Leite PC. Transmissão oral da doença de Chagas pelo consumo de açaí: um desafio para a vigilância sanitária. Vigil Sanit Debate [Internet]. 2014 [citado 2018 mar. 18];2(4):4-11. Disponível em: https://www.arca.fiocruz.br/bitstream/ icict/9712/2/Vig_Sanit_Debate_2_4-11.pdf

7. Dias JCP, Ramos Junior AN, Gontijo ED, Luquetti A, Shikanai-Yasuda MA, Coura JR, et al. II Consenso Brasileiro em Doença de Chagas, 2015. Epidemiol Serv Saúde [Internet]. 2016 [citado 2018 mar. 18];25(n.esp):7-86. Disponível em: http://www.scielo.br/pdf/ress/ v25nspe/2237-9622-ress-25-esp-00007.pdf

8. Carvalho ALB, Jesus WLA, Senra IMVB. Regionalization in the SUS: implementation process, challenges and perspectives in the critical view of system managers. Ciênc Saúde Coletiva [Internet]. 2017 [cited 2018 May 10];22(4):1155-64. Available from: http://www.scielo. $\mathrm{br} / \mathrm{pdf} / \mathrm{csc} / \mathrm{v} 22 \mathrm{n} 4 / \mathrm{en} \_1413-8123-\mathrm{csc}-22-04-1155 . \mathrm{pdf}$ 
9. Doença de Chagas aguda e distribuição espacial dos triatomíneos de importância epidemiológica, Brasil 2012 a 2016. Bol Epidemiol [Internet]. 2019 [citado 2018 mar. 18];50(2):1-10. Disponível em: https://portalarquivos2.saude.gov.br/images/pdf/2019/ janeiro/23/2018-025.pdf

10. Instituto Brasileiro de Geografia e Estatística. Cidades [Internet]. Rio de Janeiro: IBGE; 2018 [citado 2018 dez. 19]. Disponível em: https:// cidades.ibge.gov.br/

11. Coura JR. The main sceneries of Chagas disease transmission. The vectors, blood and oral transmissions: a comprehensive review. Mem Inst Oswaldo Cruz [Internet]. 2015 [cited 2018 May 10];110(3):277-82. Available from: https://www.ncbi.nlm.nih.gov/pmc/articles/ PMC4489464/

12. Guimarães RJPS, Sousa Junior AS, Pinheiro AF, Dias RS, Dias FA, Neves ALL, et al. Geoprocessamento aplicado à análise ecoepidemiológica da doença de Chagas nos municípios de Abaetetuba e Barcarena, no Estado do Pará, Brasil, entre 2000-2011. Rev SELPER. 2012;34(2):305 .

13. Carvalho RB, Silva HCS, Couto MVG. Conceição FB, Ribeiro Junior G, Bastos CJC. Perfil biossocial dos indivíduos portadores de doença de chagas atendidos no ambulatório de infectologia do Hospital Couto Maia, Salvador, Bahia. Rev Baiana Saúde Pública. 2013;37 Supl $1: 133-43$.

14. Sousa Junior AS, Palácios VRCM, Miranda CS, Costa RJF, Catete CP, Chagasteles EJ, et al. Space-temporal analysis of Chagas disease and its environmental and demographic risk factors in the municipality of Barcarena, Pará, Brazil. Rev Bras Epidemiol [Internet]. 2017 [cited 2018 May 10];20(4):742-55. Available from: http://www.scielo.br/scielo.php?script=sci_arttext\&pid=S1415-790X2017000400742\&lng= en\&nrm=iso\&tlng=en

15. Vianna EN, Guimarães RJPS, Souza CR, Gorla D, Diotaiuti L. Chagas disease ecoepidemiology and environmental changes in northern Minas Gerais state, Brazil. Mem Inst Oswaldo Cruz [Internet]. Rio de Janeiro. 2017 [cited 2018 May 18];112(11):760-8. Available from: https://www.ncbi.nlm.nih.gov/pmc/articles/PMC5661899/

16. Guhl F. Geographical distribution of Chagas disease. In: Telleria J, Tibayrenc M, editors. American trypanosomiasis chagas disease. Cambridge: Academic Press; 2017. p. 89-112.

17. Dias JVL, Queiroz DRM, Martins HR, Gorla DE, Pires HHR, Diotaiuti L. Spatial distribution of triatomines in domiciles of an urban area of the Brazilian Southeast Region. Mem Inst Oswaldo Cruz [Internet]. 2016 [cited 2018 May 18];111(1):43-50. Available from: https://www. ncbi.nlm.nih.gov/pmc/articles/PMC4727435/

18. Echeverria LE, Morillo CA. American trypanosomiasis (Chagas Disease). Infect Dis Clin N Am. 2019;33(1):119-34. DOI: https://doi. org/10.1016/j.idc.2018.10.015

19. Passos LAC, Guaraldo AMA, Barbosa RL, Dias VL, Pereira KS, Schmidt FL, et al. Sobrevivência e infectividade do Trypanosoma cruzi na polpa de açaí: estudo in vitro e in vivo. Epidemiol Serv Saúde [Internet]. 2012 [citado 2018 mar. 10];21(2):223-32. Disponível em: http:// scielo.iec.gov.br/pdf/ess/v21n2/v21n2a05.pdf

20. Pérez-Molina JA, Molina I. Chagas disease. Lancet. 2018;391(10115):82-94. DOI: https://doi.org/10.1016/S0140-6736(17)31612-4

21. Coura JR, Junqueira ACV. Surveillance, health promotion and control of Chagas disease in the Amazon Region - medical attention in the Brazilian Amazon Region: a proposal. Mem Inst Oswaldo Cruz [Internet]. 2015 [cited 2018 May 18];110(7):825-30. Available from: https:// www.ncbi.nlm.nih.gov/pmc/articles/PMC4660612/

22. Santos VRC, Meis J, Savino W, Andrade JAA, Vieira JRS, Coura JR, et al. Acute Chagas disease in the state of Pará, Amazon Region: is it increasing? Mem Inst Oswaldo Cruz [Internet]. 2018 [cited 2018 May 18];113(5):e170298. Available from: https://www.ncbi.nlm.nih. gov/pmc/articles/PMC5951676/

23. Doença de Chagas aguda no Brasil: série histórica de 2000 a 2013. Bol Epidemiol [Internet]. 2015 [citado 2018 mar. 18];46(21):1-9. Disponível em: http://portalarquivos.saude.gov.br/images/pdf/2015/agosto/03/2014-020.pdf

24. Dias JCP, Cláudio LDG, Lima MM, Albajar-Viñas P, Silva RA, Alves RV, et al. Changes in the paradigm of clinical and therapeutic management of Chagas' disease: progress and perspectives in the pursuit of comprehensive health. Epidemiol Serv Saúde [Internet]. 2016 [cited 2018 May 18];25(n.spe):87-90. Available from: http://www.scielo.br/pdf/ress/v25nspe/en_2237-9622-ress-25-esp-00087.pdf 